\title{
Why do Indonesian politicians promote shari'a laws? An analytic framework for Muslim-majority democracies
}

\author{
Elizabeth Pisani, KITLV, Leiden and Michael Buehler. SOAS University of London \\ Introduction
}

Scholars have noted a rise in the adoption of Islamic laws in Muslim-majority countries that have begun to develop their democracies. ${ }^{1}$ Subsequent studies have examined the causesand consequences of this rise. Very broadly, these studies - few of which are based on detailed empirical analysis of the passage of laws - fall in to two camps. The first explains the passage of Islamic laws as ideologically driven. Once elected, politicians seek to use their power to impose shari'a law on a larger number of people and across a wider range of social and economic areas. In other words, shari'a law is supply driven. ${ }^{2}$ The second body of literature sees the passage of shari' $a$ laws as a response of politicians to the demands or perceived preferences of their constituents, who may be voters or power brokers. ${ }^{3}$ In this case, shari'a law is seen as demand driven.

In reality, the supply and demand side interact in Islamist politics just as they do in secular economics. We have thus attempted to develop a framework which allows for a more nuanced investigation of the motivation for passage of shari'a laws. This 'alignment ofInterest' framework predicts variations in content and in the geographical and temporaldistribution of newly-adopted shari'a laws, according to the major motivation for their pas-sage. We then test this framework against an original database of regulations passed inIndonesia, the world's largest Muslim-majority democracy, between 1999 and 2012.

\section{Framework and hypotheses}

Taking the discussion in the existing literature as a starting point, we posit that there are two broad motivations for democratically-elected politicians to adopt shari'a laws and regulations: ideological conviction on the one hand and response to the expressed or perceived preference of constituents on the other hand. The 'demand side' can be further divided intothe preferences of individual voters, and the interests of groups which act as power brokers, influencing the voting choices of individual citizens. These groups may be economic, religious, or other actors.

These motivations are not mutually exclusive; the passage of a given shari'a regulation may fulfil two or all three of them simultaneously. However, we posit that the interaction between the place, timing, and content of shari'a laws passed in a nation as a whole will varyin various predictable ways, according to the dominant motivations. The dominant motiva-tion may also affect the vigour with which the law is implemented.

Shari'a laws can be enacted in many different areas of life, including religious observance, dress, family relations, marriage, finance, and much else. ${ }^{4}$ We believe that the content of the law may vary by motivation, with demand side laws being broadly more populist in nature than those enacted out of pure religious conviction. In democracies, law-making is embedded in a relatively predictable electoral cycle. The time during that electoral cycle in whicha law is proposed or enacted is likely to be influenced by law-makers' reasons for proposing the law. In the case of demand-driven laws, campaign periods may produce different types of regulations compared with periods in which an incumbent can no longer run for re-elec-tion for example. Geographical variation is highly country-specific. In any given Muslim- 
This is the accepted version of an article published online by Taylor and Francis in Third World Quarterly on 29 July 2016. Published version available at: http://www.tandfonline.com/doi/full/10.1080/01436597.2016.1206453 Accepted version downloaded from SOAS Research Online: http://eprints.soas.ac.uk/22731/

majority democracy, we expect areas with a long culture of involvement in political Islam to produce more shari'a regulation on the demand side, but not necessarily on the supply side. In some countries, laws and regulations are passed with much greater frequency than they are implemented. We believe variations in implementation of shari'a regulations may provide some clues to the motivation for their passage.

Our framework delineates three broad constellations of these variables. The content, timing, geographical distribution, and implementation of shari'a regulations in each constellation interact in predictable ways, and each maps on to a dominant motivation.

\section{Pattern 1: supply side motivation; religious ideology}

Politicians motivated principally by religious ideology are least influenced by the preference of the electorate. We would expect the laws they pass to encompass all aspects of religious doctrine equally, and we would expect those laws to be passed either with no discernible regard for the electoral cycle, or shortly after initial election when they first have the opportunity to extend their ideologies to others through the force of law. In decentralised systems, we would also expect these regulations to be distributed relatively evenly across a nation.

Table 1. alignment of interests: hypothesised patterns in passage of shari'a laws, for different primary motivations.

\begin{tabular}{lllll}
\hline Pattern & Content & Timing & Geographical distribution & Implementation \\
\hline ideologically & Broad & on election/low & universal & universal \\
appeal to voters & Popular/ & Campaign periods & highly variable & When re- \\
$\begin{array}{l}\text { appeal to } \\
\text { power }\end{array}$ & delivering & low variation & Variable & universal \\
\hline
\end{tabular}

In addition, we expect that politicians who pass laws out of ideological conviction are likely to make significant efforts to see those laws implemented.

\section{Pattern 2: demand side motivation; direct appeal to voters}

In contrast, elected politicians who pass laws with the intention of supporting their own re-election are clearly interested in appealing to voters. When that appeal is direct - to individual voters - we would expect the regulations to focus on those aspects of religious law deemed to be popular or even populist, and for the passage of laws to cluster in campaign periods. Where there are strong regional variations in voter preferences, we would expect those to be reflected in the passage of regulations. In terms of implementation, we would expect it to be more forceful in periods when an incumbent has a chance of being re-elected than when they do not.

\section{Pattern 3: demand side motivation; appeal to power brokers}

Politicians intent on appealing to power brokers will choose areas of religious law that meet the needs of those various interest groups. Because patronage relationships involve mutually beneficial ties that are developed and can persist over many election cycles ${ }^{5}$ we would expect less temporal variation in the passage of laws that appeal to this group. Geographically, we would expect less of a variation in volume than seen in laws designed to appeal directly to 
This is the accepted version of an article published online by Taylor and Francis in Third World Quarterly on 29 July 2016. Published version available at: $\underline{h t t p: / / w w w . t a n d f o n l i n e . c o m / d o i / f u l l / 10.1080 / 01436597.2016 .1206453 ~}$ Accepted version downloaded from SOAS Research Online: http://eprints.soas.ac.uk/22731/

voters. However, variations in the specific content of patronage-conferring laws are possible, with those appealing to religious brokers more common in more strongly Islamic areas. To be effective, patronage must be delivered, so we would expect implementation rates to be high.

These variations are summarised in Table 1.

Though this characterisation is simple, we believe that it might provide a useful starting point for disentangling the motivations for of the passage of shari'a laws in different countries and different electoral systems. While the passage of any given law may have overlapping motivations, the analysis of patterns in the passage of laws at a national level may reveal that some patterns predominate in a given country or at a given time period, thus revealing differences between regions or over time.

as a starting point, we try to the extent possible to validate this framework using data from Indonesia, the world's largest Muslim democracy, and one that has been enthusiastically passing local regulations for a decade and a half. 


\section{Background to the data-set: democratisation, decentralisation and law- making in Indonesia}

For over half of its 71-year existence, Indonesia was ruled from the capital Jakarta, with no real participation from the electorate. The heads of provinces, districts and municipalities were appointed by the central government and implemented their programmes with little variation. ${ }^{6}$ They had little incentive to respond to the needs or desires of citizens. after the collapse of the new Order regime in 1998, Indonesia's national government adopted free multi-party elections. Since 1999, the country has held free and fair elections every five years, contested by as many parties as meet the registration criteria.

at the same time as Indonesia was re-establishing multi-party elections after decades of authoritarian rule, it embarked on a radical programme of decentralisation. From 2001, in recognition of Indonesia's extraordinary ethnic, cultural, and economic diversity, districts (and to a lesser extent provinces) acquired unprecedented powers to make decisions locally. Policy and spending decisions about health, education, industry, and many other areas of life are made by district governments, consisting of an executive and a legislative branch. Since 2005, district heads and provincial governors have been directly elected by the local citizenry. at the time of writing, local government heads could be elected for up to two five-year terms. If they wish to run for office after completing two terms, they must seek office at a different level.

Indonesia remains a multi-faith state and all citizens are encouraged to list one of six religions on their identity card: Islam, Catholicism, Protestantism, Hinduism, Buddhism, or Confucianism. Some $87 \%$ of Indonesians profess Islam, but there are important regional variations. In aceh province, which describes itself with pride as 'the Veranda of Mecca', 98.2\% of residents reported being Muslim in the 2010 census, compared with just $66.1 \%$ in neighbouring north Sumatra, which has a large Protestant community. In Bali (predominantly Hindu) and large swathes of Eastern Indonesia (with Christian majorities) less than a third of Indonesians are Muslim. ${ }^{7}$ among the Muslim-majority regions, some areas have stronger historical links with Islamist movements than others. In the 1950s and early 1960s, rebels hoping to establish a pan-Indonesian Islamic state were active in aceh, West Sumatra, the western part of Java, South Sulawesi, and South Kalimantan.

religious affairs were one of the areas that were retained under the authority of the central government under law 22/1999 governing local government. Because of this, and because Indonesia is constitutionally a multi-faith nation, provinces and districts are not allowed to issue shari' $a$ or other religious regulations. aceh province is an exception. In an effort to reduce support for a separatist insurgency by according the province special privileges, the Indonesian government has since 2001 allowed aceh to pass shari'a regulations.

although subnational jurisdictions must operate within the legal framework of the unitary state, in order to meet local needs local governments are permitted to pass local regulations that complement national laws. Several jurisdictions have used this loophole to adopt local regulations and executive orders ${ }^{8}$ on issues that are derived exclusively from Islamic teachings. Concretely, local regulations have been adopted on dress codes for Muslims and obligations to pay religious alms. In addition, many districts have passed laws that stress public morality - prohibitions on alcohol and prostitution, for example - that are generally inspired by religious teachings and enabled by a climate of conservatism but that may not be enshrined exclusively in Islam. We recognise that in the Indonesian legal context none of 
these regulations may technically be termed 'shari'a regulations', except in aceh province. However, we use the term in this article for convenience, to avoid repetition of the clumsier phrase 'Islam-inspired regulations'. It is these laws, described at greater length in the methods section below, which are collected in our validation data-set.

\section{Validating the 'alignment of interests' framework for Indonesia}

The conflicting views characterising the broader debate on what causes the rise of shari'a laws in democratising Muslim-majority countries are reflected to some extent in the scholarship on the adoption of shari'a regulations in democratising Indonesia.

a few anthropologists and other scholars, some drawing observations from a single sub-district, have interpreted the adoption of shari' $a$ regulations as an indication that Islamist ideologies are making inroads into Indonesian politics. ${ }^{9}$ This view has certainly been reflected in public discourse: a typical example is provided by a New York Times article entitled 'Extremism Spreads across Indonesian Penal Code'. ${ }^{10}$

The majority view, on the other hand, is that Islamist parties and interest groups are a very long way from setting the political agenda in Indonesia. Several studies suggest that in adopting shari'a regulations, politicians are primarily thinking not about religious ideology but about their re-electability. The adoption of shari'a regulations has been attributed to growing pressure on Indonesian politicians with a hitherto secular outlook to mobilise the masses. ${ }^{11}$ Other studies have said that it is a clumsy way for politicians to signal to a newly empowered electorate that they take the rule of law seriously. ${ }^{12}$ Some scholars see it as an expression of sub-national jurisdictions'more assertive stance vis-à-vis the national government. ${ }^{13}$ Finally, some studies have said that the adoption of shari'a regulations is to be seen as a sign of outright political corruption and rent-seeking as shari'a regulations allow politicians to control the collection (and distribution) of religious alms. ${ }^{14}$

Political party affiliations remain weak in Indonesia - politicians often switch parties even when they are at the level of vice president or cabinet minister - so politicians work hard to project their own personalities and to build up personal support networks. ${ }^{15}$ a handful of 'democratic entrepreneurs'have emerged; politicians who focus their energies on delivering benefits directly to the electorate. ${ }^{16}$ More commonly, however, candidates for governor and district head promise many benefits to voters, but actually deliver most benefits to influential individuals or groups who may be able to rally blocks of votes. ${ }^{17}$ The Indonesian media commonly uses the English phrase'money-politics' to describe the undertow of patronage and clientelism that characterise these local elections, and scholars have recently begun to investigate more rigorously the mechanisms through which such patronage operates. ${ }^{18}$ networks identified as potentially providing support for candidates include religious leaders with significant congregations (especially in rural areas), and vigilante groups, including those which rally under Islamist banners.

applying the 'alignment of Interest' framework above to a data-set of shari'a regulations passed in Indonesia, we would thus expect to find very limited evidence of purely ideological motivation (little sign of Pattern 1), strong evidence of appeal to power brokers (significant presence of Pattern 3), and moderate evidence of appeal direct to the electorate (some presence of Pattern 2).

To our knowledge, this is the first study to try to analyse empirically the interaction between the content of shari' $a$ laws and the timing and distribution of their passage and 
implementation in a large Muslim-majority democracy. We hope it will yield insights into ways of structuring investigations around Islamisation and democracy.

\section{Methods}

To establish a data-set of shari'a regulations in Indonesia, we began with records from the Ministry of Home affairs (MoHa) which, in theory, is mandated to archive all local regulations. In practice, data available at the MoHa are incomplete due to a time-lag between the adoption of local regulations by sub-national jurisdictions and their reporting to the national government as well as the weak capacity of the MoHa. Many local regulations do not get reported at all. an increasing number of jurisdictions list the local regulations they adopt on their internet website, so to verify and amend the data obtained from the MoHa, we checked the website of every jurisdiction in Indonesia. We also used existing compilations of religious regulations collected by watchdog organisations and journalists and conducted systematic searches in national and local newspaper archives. Finally, we conducted several dozen interviews with government officials, civil society organisations, and Islamist activists on the ground in Indonesia between 2005 and 2014.

after reading the text of each regulation, we classified it by subject matter into one of 10 subgroups, namely:

(1) Collection of religious alms (Zakat, Infaq, and Shadaqah)

(2) Promotion of Islamic knowledge and skills through Islamic education

(3) Islamic finance (the prohibition of usury)

(4) Propagation of 'proper faith'and prohibition of Islamic sects deemed unorthodox

(5) dress codes

(6) Other religious regulations pertaining to Islamic teachings such as mandating

Qur'an-reading tests for political candidates

(7) Prohibition of gambling

(8) Prohibition of the consumption of alcohol

(9) Prohibition of prostitution

(10) Prohibition of unspecified 'sins'19

Since local governments outside of aceh province are not technically permitted to issue religious laws, as mentioned above, the classification of individual regulations as shari'a was not always straightforward. The first seven of the content groups are derived exclusively from Islamic teaching and can confidently be said to mirror shari'a laws. 1aws relating to prostitution and alcohol, on the other hand, could be regarded as public order laws, intended to reduce violence and other social harms associated with commercial sex or alcohol abuse. regulations that have clear public health goals, for example those decreeing the use of condoms in commercial sex, were not included in our database. Other local regulations, however, attempt to prohibit prostitution and the consumption of alcohol outright. These regulations deviate from national law - the production, sale, and consumption of alcohol is legal in Indonesia, as is the sale of sex (although pimping is prohibited). regulations prohibiting these behaviours (rather than restricting and moderating them) tend to be moralising in intent, and some of them also include scriptural language. They reflect a climate of social conservatism consistent with the passage of the types of shari'a regulations mentioned 
above. We have therefore included them in the database of shari'a legislation, but have performed analysis with and without these two categories.

In order to align the content of different types of regulations with our proposed framework, we further categorised the shari'a regulations we collected in terms of their potential appeal to different constituencies. We established three categories:

- regulations that appeal primarily to local governments and are most likely to be exclusively supply driven. The only regulations falling in to this category are those that govern the collection of religious alms. These bring cash legitimately into the coffers of the local government, but impose taxes on Muslim citizens and, arguably, are thus unpopular with the electorate.

- Shari'a regulations that increase patronage opportunities and allow local government heads to expand local networks of influence. These include the promotion of knowledge through Islamic education, obliging children and sometimes adults to attend private Islamic schools to improve their Qur'an reading skills. Such regulations often introduce elaborate payment schemes for Qur'an reading teachers, who are potentially influential vote-brokers in local politics. religious regulations on strengthening Islamic education can therefore be seen as a way to put social cosmetics on patronage politics. ${ }^{20}$ rules regulating finance to ensure compliance with Islam's prohibition of usury create opportunities to channel the public budget through certain banks and financial institutions. These present clear opportunities to dole out favours to key individuals in the local economy. We also placed shari'a regulations prohibiting prostitution, gambling, and alcohol into this category, because of the well-established practice of allowing Islamicthemed vigilante groups to collect protection money from those violating these rules. ${ }^{21}$ These groups are also potentially important in campaigning and getting the vote out, come Election day.

- Shari'a regulations designed to appeal directly to the electorate. These measures have no instrumental value other than boost the Islamic credentials of the local governments that adopt them. The regulations in this group include those on dress codes (such as obliging women to cover their heads), those that prohibit Islamic sects seen as deviant, and those that promote public expression of religion such as the very popular and well-attended Koran-reading competitions. also included in this category is the generalised, non-specific prohibition of 'sin'.

We jointly developed proposed classifications, focusing initially on the primary benefits to district heads, and discussed them with scholars, journalists, and other observers of Indonesian politics until consensus was reached. Following comments from reviewers, we expressed these clusters in terms of the constituencies they were designed to appeal to, since it is through these constituencies that benefits accrue to politicians.

We recognise that there is a high degree of subjectivity in these classifications, not least because there is some overlap among these categories. In aceh, for example, a formal, statefunded'shari'a police'enforces some of the'reputation-enhancing'laws such as dress codes. The very existence of this additional workforce in itself creates patronage opportunities, and more are created in the exercise of their duties.

In discussing categorisation, we tried to focus on identifying the constituency for whose intended benefit the regulation is primarily proposed. The shari'a police do not themselves carry much weight with the electorate. In this case, the patronage opportunity is a by-product 
of a regulation whose primary political aim is more likely to be the alignment of the image of a politician as a pious Muslim with the supposed preferences of the electorate. In other words, by enacting such regulations, local legislators are intending primarily to appeal directly to voters, not to interest groups.

In order to investigate variations in the geographical distribution of regulations, we created a binary variable reflecting historical links with Islamist activism. The provinces of aceh, West Sumatra, West Java, Banten, South Kalimantan, and South Sulawesi, which all rebelled against the republic of Indonesia under the banner of Islam at some point in the twentieth century, score positive for this variable.

The electoral cycle for the top executive government posts in Indonesia runs in five-year terms, with each person eligible to serve up to two terms as president, governor, or district head. To investigate temporal variations in the passage of shari'a regulations, we further divided each cycle into two periods of 2.5 years, giving a possible political life of four periods. Two of these immediately follow election or re-election, one covers the time when a firsttime district head is likely to be campaigning for re-election, and one, the final 2.5 year period of a possible 10 years in a given office, covers the period in which the incumbent faces mandatory retirement from the post.

The proposed framework includes an analysis of the implementation status of the various regulations. We were unable to obtain these data systematically for all regulations and all areas. However, we did collect qualitative data in numerous in-depth interviews with government officials, civil society organisations, and Islamists in the capital and districts in South Sulawesi and West Java province. ${ }^{22}$ Based on these data, we present some preliminary thoughts about the likely validity of our hypotheses relating to implementation.

data were initially entered and coded in Excel, then exported to Stata 11 for analysis. The primary unit of analysis was the regulation. In other words, each separate regulation carried the same weight in the analysis, regardless of whether or not they were passed by the same individual.

Maps were made using shape files describing provincial and district boundaries extant in 2012, the end of the period under review. Statistical significance was tested using a twosided chi squared distribution. results reported as 'significantly different' have $p \leq .05$.

\section{Results}

Overall, we collected and classified 442 local shari'a regulations enacted between 1999 and 2012. Of these, two-thirds $(292,65.9 \%)$ were enacted in rural districts, ${ }^{23}$ a quarter $(109,24.6 \%)$ in municipalities, and the remainder $(42,9.5 \%)$ by provincial governments. Most took the form of peraturan daerah or local regulations, meaning they passed through the local legislature. Some $16 \%$ were regulations issued as executive orders by the head of the local government. Overall, 254 individual politicians passed religious regulations at the provincial or district level in Indonesia between 2001 and 2012.

We present the remainder of the results in accordance with the framework, looking at the distribution of regulations across different areas of content, across the electoral cycle, across geographical areas. We then look at the interaction between these areas. 
This is the accepted version of an article published online by Taylor and Francis in Third World Quarterly on 29 July 2016. Published version available at: $h$ ttp://www.tandfonline.com/doi/full/10.1080/01436597.2016.1206453 Accepted version downloaded from SOAS Research Online: http://eprints.soas.ac.uk/22731/

Table 2. Number and distribution of shari' $a$ regulations passed in indonesia, 1999-2012, by content, for historically islamic provinces and other provinces.

\begin{tabular}{lccc}
\hline & Former Islamic rebellion & no Islamic rebellion & Total $^{*}$ \\
\cline { 2 - 4 } & $n(\%)$ & $n(\%)$ & $n(\%)$ \\
\hline religious alms & $40(15)$ & $28(16)$ & $68(15)$ \\
islamic education & $54(20)$ & $16(9)$ & $70(16)$ \\
Shari'a finance & $22(8)$ & $21(12)$ & $43(10)$ \\
Prohibits sects & $21(8)$ & $9(5)$ & $30(7)$ \\
dress codes & $24(9)$ & 0 & $24(5)$ \\
Public display of islamic knowledge & $21(8)$ & $4(2)$ & $25(7)$ \\
Prohibits alcohol & $44(17)$ & $49(28)$ & $93(21)$ \\
Prohibits prostitution & $13(5)$ & $36(21)$ & $49(11)$ \\
Prohibits gambling & $4(2)$ & 0 & $4(1)$ \\
Prohibits 'sin' & $24(9)$ & $12(7)$ & $36(8)$ \\
ToTal & $267(100)$ & $175(100)$ & $442(100)$ \\
\hline
\end{tabular}

*Percentages may not add to 100 because of moundino

\section{Content}

Over a fifth of all regulations restricted the sale or consumption of alcohol - the single most common area for regulation. The promotion of Islamic education came next at $16 \%$, with the collection of religious alms at $15 \%$. (details can be seen in Table 2.) Collapsing regulations into categories which try to capture their primary potential beneficiaries, we find that a majority of regulations provide patronage opportunities for the benefit of special interest groups - fully $57 \%$ of the total. a further $26 \%$ are designed to appeal primarily to voters by showcasing the piety of local government, while the remaining $15 \%$ impose taxes, appealing only to the government itself.

\section{Timing}

Overall, $68 \%$ of the shari'a regulations in our database were passed during a governor or district-head's first term in office. This is not unexpected since some politicians were voted out of office or gaoled for corruption after just one term. among both first- and second-term regulations, a minority ( $46 \%$ and $47 \%$ respectively) were passed in the first half of the period. The single most active period for passing shari'a regulations was in the second half of the first term, when the incumbent was likely to be seeking re-election.

\section{The geographical expression of history}

Figure 1 shows the distribution of shari' $a$ regulations across Indonesia. aceh, which is unique among Indonesian provinces in being permitted to pass formal shari'a laws, accounted for over a third of all religious regulations passed at the provincial level (15/41).

With the exception of East Java, all the provinces that passed 20 or more shari'a regulations at the provincial and district levels combined over the period under review were sites of Islamist-identified rebellions against the national government in Jakarta during the early decades of the republic of Indonesia. ${ }^{24}$ Those provinces accounted for $23 \%$ (115/497) of all districts and municipalities in Indonesia at the start of 2012, the final year covered by this study. In terms of the shari' $a$ regulations passed, however, they accounted for fully $60 \%$. 
This is the accepted version of an article published online by Taylor and Francis in Third World Quarterly on 29 July 2016. Published version available at: $\mathrm{http}: / / w w w . t a n d f o n l i n e . c o m / d o i / f u l l / 10.1080 / 01436597.2016 .1206453$ Accepted version downloaded from SOAS Research Online: http://eprints.soas.ac.uk/22731/

Table 3. Number and distribution of shari'a regulations passed in indonesia, 1999-2012, by primary potential beneficiaries, for historically islamic provinces and other provinces.

\begin{tabular}{lccc}
\hline \multirow{2}{*}{$\begin{array}{l}\text { Primary political beneficiary } \\
\text { ofregulation }\end{array}$} & Former Islamic rebellion & no Islamic rebellion & Total \\
\cline { 2 - 4 } Government & $n(\%)$ & $n(\%)$ & $n(\%)$ \\
interestgroups & $40(15)$ & $28(16)$ & $68(15)$ \\
Voters & $137(51)$ & $122(70)^{*}$ & $259(57)$ \\
\hline
\end{tabular}

*difference is statistically significant at the $p<.000$ level.

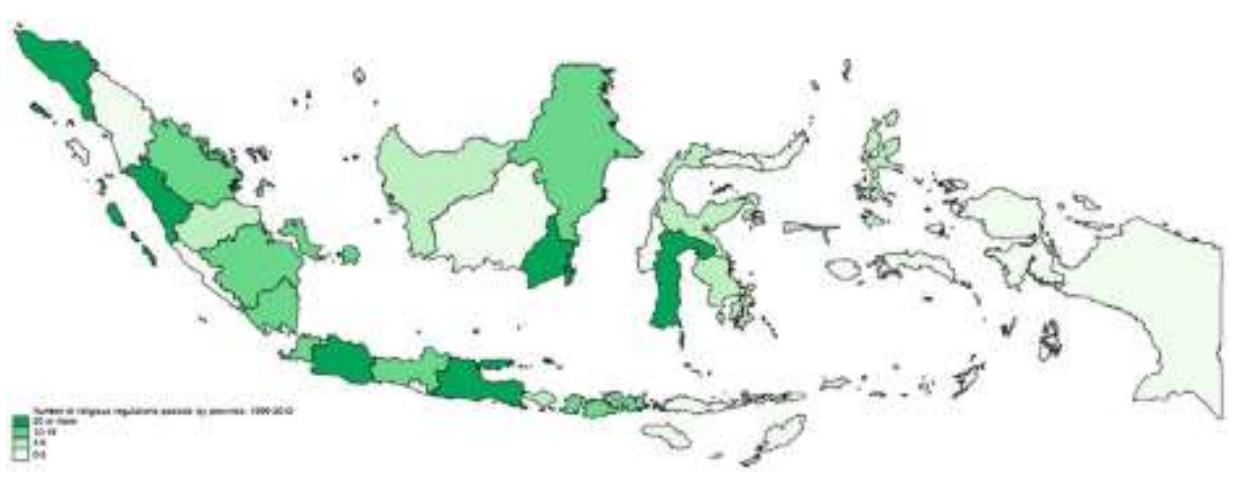

Figure 1. Number of shari'a regulations enacted in indonesia at the provincial or district level between 1999 and 2012, by province.

\section{Interaction between content and history}

as Table 2 shows, the distribution of the content of regulations varies by a region's history. In areas that have not historically had links with Islamist movements, $49 \%$ of all of the regulations in the database relate to alcohol and prostitution, compared with just $22 \%$ in more historically Islamic provinces $(p<.000)$. If these more generalised'morality-based'regulations are excluded from the analysis, then the concentration of shari'a regulations in historically Islamic areas rises to $70 \%$.

When these groups are collapsed by primary potential beneficiary or'target audience' as in Table 3, we see a clear pattern linking history and content. regulations that only meet the interests of government are evenly distributed. Shari'a regulations intended to appeal directly to voters were more than twice as likely to be passed by provinces and districts with a strong history of Islamic political organisation, compared with historically less Islamist areas. Some $34 \%$ of regulations passed in provinces that were Islamist strongholds promoted piety, compared with just $14 \%$ of those on other areas $(p<.000)$. Fully $70 \%$ of the regulations passed in less Islamist areas could be classified as providing patronage opportunities to potential vote-brokers.

Within those regulations providing patronage opportunities, there were strong regional variations in actual content. In areas with a history of Islamic rebellion, fully $56 \%$ of regulations potentially benefiting interest groups mandated Islamic teaching or finance, while only a minority, 44\%, were morality-based. In other areas of Indonesia, however, $70 \%$ of all regulations of potential benefit to interest groups dealt with alcohol or prostitution. 


\section{Interaction between content and timing}

In looking at the interactions between the content and timing of laws, we have grouped the first half of the first and second terms to represent all periods in which a district was headed by someone recently elected or re-elected. The second half of the first term represents the campaigning period, when an incumbent is likely to have their eyes on the chance of re-election. The second half of the second term represents the legacy period, during which a candidate is coming to end of his or her popular mandate, and is not able to run again for the same post.

regulations that carried patronage opportunities were the majority during every part of the election cycle, and did not differ significantly between electoral periods. However the regulations on the collection of religious alms that generate revenue at the expense of Muslim members of the electorate were significantly less likely to be passed during the campaigning cycle than at other times $(p=.01)$. In fact, they were most likely to be passed in a local government head's final term in office, when re-election to the post was no longer possible, as shown in Figure 2.

regulations thought to appeal to voters by highlighting a leader's image as a pious person, on the other hand, were more than twice as likely to be passed in the campaign cycle compared with times when the incumbent could not be re-elected $(p=.02)$.

\section{Interaction between content, timing, and history}

The interactions between content and timing were accentuated when a region's history was also taken into account, as Figure 3 shows.

In historically less Islamist areas, not a single regulation promoting a leader's credentials as a good Muslim was passed when that leader was unable to seek re-election, while in provinces with a history of Islamic political engagement, over a quarter of regulations passedin this ‘legacy’ period were largely signals of piety, with only limited monetary or patronage

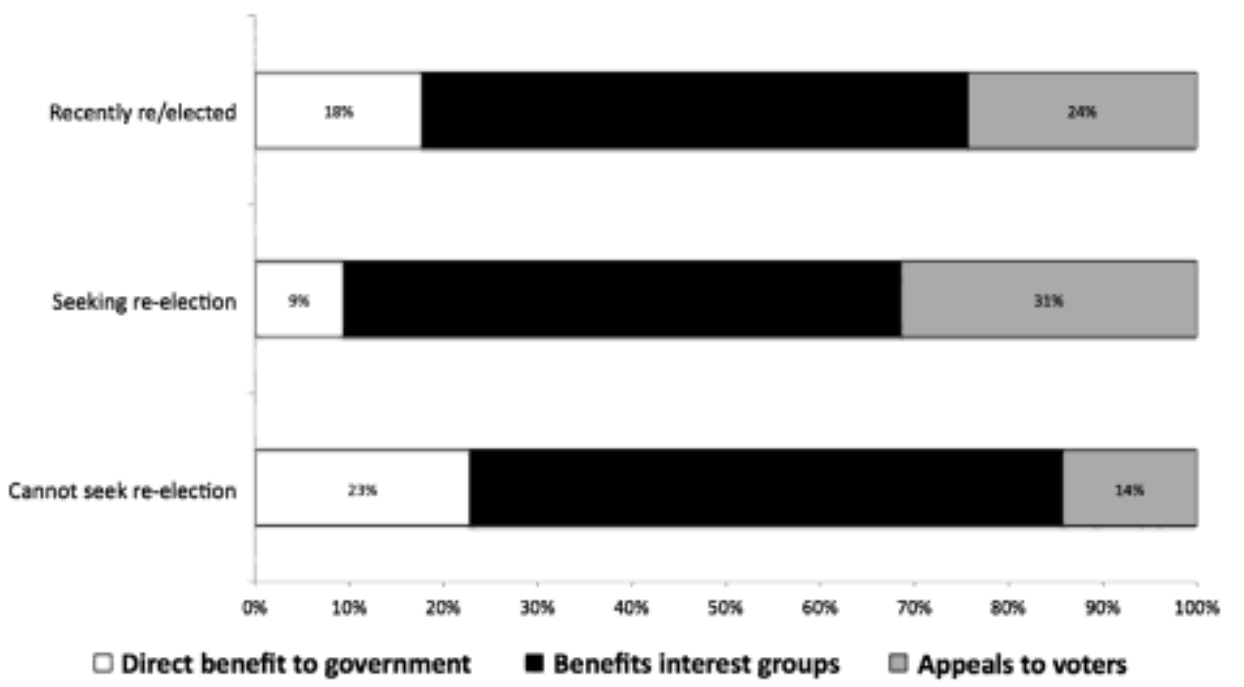

Figure 2. Percentage distribution of shari'a regulations passed in indonesia 1999-2012, by primary potential beneficiary and time in election cycle. 
This is the accepted version of an article published online by Taylor and Francis in Third World Quarterly on 29 July 2016. Published version available at: $\mathrm{http}: / / w w w . t a n d f o n l i n e . c o m / d o i / f u l l / 10.1080 / 01436597.2016 .1206453$ Accepted version downloaded from SOAS Research Online: http://eprints.soas.ac.uk/22731/

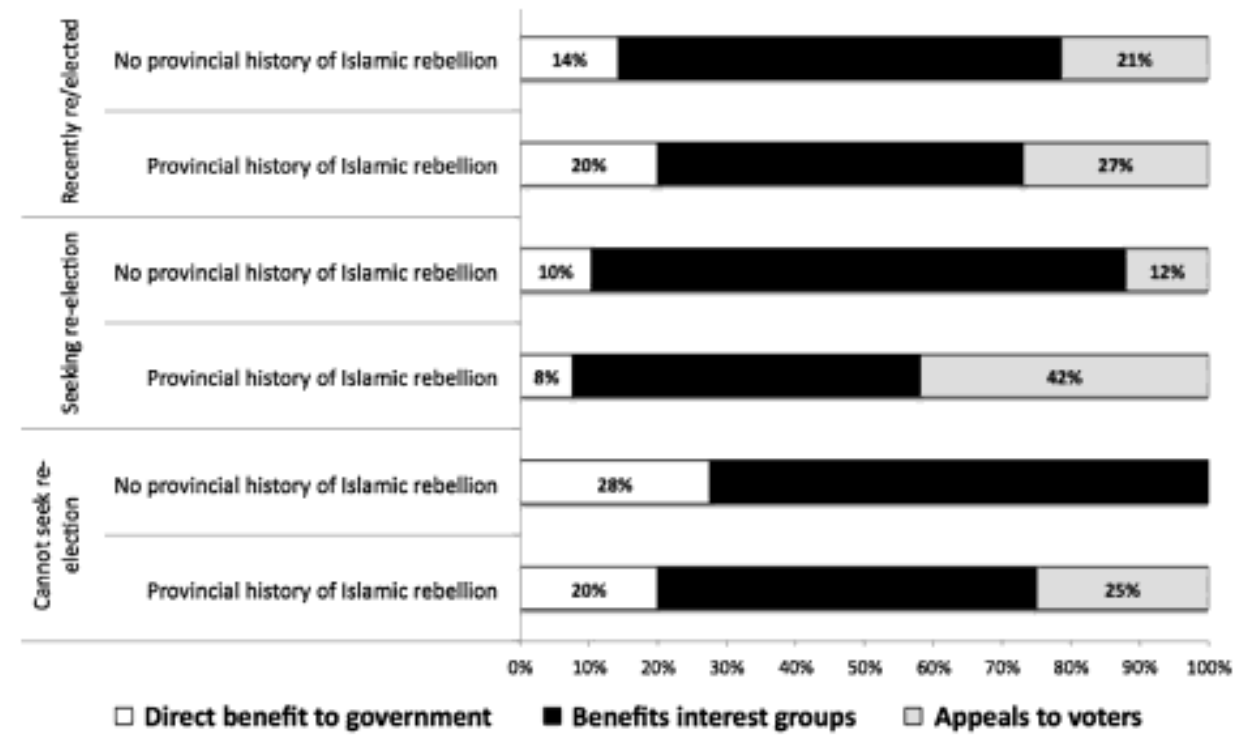

Figure 3. Percentage distribution of shari'a regulations passed in indonesia 1999-2012, by primary potential beneficiary, time in election cycle, and provincial history of islamist rebellion.

benefit. during campaign periods, incumbents in former Islamist rebel strongholds were especially likely to pass regulations that reflected well on their religious sensibilities.

The pattern remains the same, and the differences in distribution of regulations by broad potential political benefit remain statistically significant if regulations prohibiting prostitution and alcohol are excluded from the analysis (data not shown).

\section{Qualitative evidence: influence and implementation}

In-depth interviews with Islamist groups suggest that they see themselves as the motivating actors for the passage of shari'a regulations. They use campaign periods as a time to exert leverage over incumbents to pass laws, while extracting promises from other candidates about future implementation. They are not always successful.

In the staunchly Muslim West Java district of Cianjur, Islamist activists felt betrayed after the 2006 elections in which the incumbent, who had himself passed nine shari'a laws, was defeated. Though the victorious candidate was backed by the Prosperous Justice Party, the most Islamist of all of Indonesia's mainstream parties, he did not follow through on an Islamist agenda, passing no new shari'a regulations during the period of this study. ${ }^{25}$ Chep Hernawan, the leader of Cianjur's largest Islamist group, GarIS, said in an interview: 'The current gov-ernment are assholes [brengsek]. If it is just us [fighting for Islam] it is difficult if the govern-ment is not pro-active' ${ }^{26}$

Politicians, for their part, are relatively open about using shari'a regulations as an instrument to expand networks among interest groups. an example comes from Patabai Pabokori, who was appointed district head of Bulukumba in the conservative Muslim province of South Sulawesi during the new Order period. at the time, local leaders faced no electoral incentives to please citizens, and Pabokori showed no evidence of strong religious conviction. In 
democratising Indonesia, however, Pabokori announced plans to turn Bulukumba into a 'warehouse [gudang] of people knowing the Qur'an by heart'. He paid uS\$1500 (Idr 15 million) to every pesantren that committed to teaching students to know the Qur'an by heart (tahfiz), ${ }^{27}$ and published photographs that show him distributing money to religious notablesin Bulukumba district. ${ }^{28}$

Besides delivering to Islamic interest groups, this religious fervour was apparently designed to appeal to voters, through successive electoral cycles. Those who followed the 'Crash Programme in religiosity'[Crash Program Keagamaan] were given'degrees'. However the imposition of a religious tax to fund a mosque-building programme undermined that goal. The tax, imposed selectively on bureaucrats for practical reasons, led to a stream of complaints to a South Sulawesi newspaper. One local bureaucrat railed that if his salary was cut each month for infaq, sadaqah, and zakat payments, which were then allegedly used for mosque projects run by the district head, he at least would expect these mosques to be really built. So far, the sender informed the newspaper, not much had happened in that respect. ${ }^{29}$

local Islamist activists in Bulukumba reinforced the fact that the regulations designed to woo voters were not always implemented in practice. ahmad Kadir, the head of the local Islamist group Forum Pembela Islam, complained in an interview in 2012:

The local government is not serious about enforcing the shari'a regulations which it has adopted in past years. I come to the district head office every week to remind the district head of these regulations. last year we gave [the district head] an ultimatum that we would take the enforcement into our own hands. ${ }^{30}$

In an interview, Patabai Pabokori inferred that the passage of shari'a regulations had also allowed him to extend his influence in non-religious circles: 'The money from zakat [collection] is for the poor. There are many thugs among poor people. If you give them money, then they keep quiet'. He went on to say that crime levels in Bulukumba district had dropped after the adoption of shari'a regulations, because petty criminals and thugs were effectively taken on to the payroll of the district government. ${ }^{31}$

\section{Discussion: the 'Alignment of Interest' framework in the Indonesian context}

Here, we attempt to fit the Indonesia data to our proposed framework, comparing the results with expectations.

\section{Pattern 1: supply side motivation; religious ideology}

The pattern expected for situations in which religious ideology is an important motivator among politicians for the passage of shari'a laws in a country is: even distribution of shari'a laws across content type, geography, and time (though with a possible peak soon after first election) and strong implementation. Based on the majority of the literature examining Islamist engagement in Indonesian politics, we expected to find little evidence of thispattern.

That has been the case. There are marked variations in the content, timing, and geographical distribution of the passage of shari'a laws across Indonesia. Qualitative evidence suggests that strong implementation of the laws that do get passed is not the norm. Our analysis 
This is the accepted version of an article published online by Taylor and Francis in Third World Quarterly on 29 July 2016. Published version available at: http://www.tandfonline.com/doi/full/10.1080/01436597.2016.1206453 Accepted version downloaded from SOAS Research Online: http://eprints.soas.ac.uk/22731/

gives little indication that'Extremism Spreads across Indonesian Penal Code'type narratives reflect reality; we believe this accords with most scholarship on the subject.

\section{Pattern 2: demand side motivation; direct appeal to voters}

The pattern expected for situations in which politicians pass regulations in large part as a way of appealing to individual voters is: content that reflects well on a candidate, very high variability across the political cycle, and very high variability between geographic areas. We expect implementation to be more pronounced for first term administration. Given the high geographic diversity of Indonesia, the personality-driven nature of campaigns and very high voter participation in local elections, we would expect this pattern to be rather pronounced in Indonesia.

again, our findings accord with this expectation. In areas where Islam is deeply culturally and politically embedded and voters may be expected to have a preference for a visibly pious leader, regulations that indicate piety but have little other instrumental value were passed very much more commonly than they were in other areas of Indonesia, both in absolute numbers and as a proportion of all shari'a regulations passed. They were also passed most actively in the second half of the first term in office, a time at which most incumbents are positioning themselves for re-election. The limited qualitative data available suggest that leaders who pass regulations designed to heighten their appeal to voters often do little to enforce them. In our framework, we would expect to see greater efforts at enforcement in the first term in office, be we do not have enough systematic evidence either to support or refute this. This underscores the need for more rigorous collection of data related to the implementation of local regulations.

In areas that have less deeply rooted links with Islamist movements, regulations designed to appeal directly to the electorate were less commonly passed. While that was in line with our proposed framework, we would have expected to see those supposedly populist regulations that were passed peak in the campaign period. This was not the case. We note, however, that not a single second-term incumbent facing retirement from the post of district head in a less historically Islamist area passed any regulation which had no instrumental value other than to enhance a reputation for religious piety.

\section{Pattern 3: demand side motivation; appeal to power brokers}

Many scholars have presented evidence of the deeply transactional nature of Indonesian democracy, and in particular the importance of power brokers and interest groups in influencing voters at the local level. In the Indonesian context we would thus expect strong evidence of this third pattern, in which the content of the regulations passed confer patronage opportunities on interest groups, usually by providing mechanisms for them to raise money. We would expect the particular nature of the patronage opportunities, though not necessarily their extent, to vary geographically to accord with culturally-embedded commitment to Islam. However because patronage relationships are built and maintained over time, we would expect limited variation across the electoral cycle. Implementation is expected to be high in this pattern.

Once again, our findings largely concur with the framework. In Indonesia, regulations conferring patronage opportunities are by far the most commonly passed of all the subsets 
of shari'a regulations, regardless of the political and cultural history of the area. However, there is geographical variation within those patronage regulations. In historical Islamist strongholds, they are more likely to focus on Islamic teaching, which plays to the interests of the religious leaders who are potentially powerful locally. In other parts of the country, most regulations relate to prostitution and alcohol, domains over which vigilante groups of many religious and political persuasions hold sway. In terms of timing, there is, as expected, less cyclical variation in the passage of these types of regulations - they make up the majority of regulations passed in every period.

Our framework predicted that these regulations should be implemented in order to deliver patronage, but qualitative evidence point to an alternative view. requirements for religious education and shari' $a$ finance only benefit interest groups when they are enforced by the local government, and in those cases, we would continue to expect strong implementation. However, regulations prohibiting prostitution or restricting alcohol in fact benefit vigilante-style interests groups precisely when they are not enforced by the local government. This allows vigilante groups to take the law into their own hands, as threatened by Forum Pembela Islam in Bulukumba. In other words, it is this lax enforcement by the local government that provides the opportunity for protection rackets.

We believe that the implementation parameter of our proposed framework may need revision as more data become available and it can be more thoroughly validated. Overall, however, we conclude that the framework fits well with the Indonesian data. Careful analysis of the content, timing, geographic distribution, and to a lesser extent implementation of shari' $a$ regulations passed between 1999 and 2012 yields the following picture: a nation in which the passage of shari'a regulations serves first the demands of a clientelistic electoral system (Pattern 3), then the desire of politicians to appeal directly to the electorate (Pattern 2). The passage of shari'a laws in Indonesia provides very little evidence of an ideological- ly-driven Islamising agenda among politicians (Pattern 1). This general picture conforms well to the consensus among scholars of Indonesia as to the relationship between democracy and political Islam in the country. With caution, then, we consider the proposed framework validated for the Indonesian case.

\section{Limitations}

Our caution derives in part from the limitations of our data. Firstly, we had very little data with which we could validate the parameter relating to implementation. Secondly, the division of the electoral cycle into two and a half year periods gives at best a crude indication of the alignment of the passage of regulations with the political exigencies of the day. Further, we recognise that the majority of regulations (some $85 \%$ of those in our database) pass through the local parliament. Parliamentarians and political parties may therefore also have been instrumental in both initiating regulation and in reaping any electoral rewards that it brought, and the electoral cycle of the parliament in Indonesia does not match that of the district head. during the period under review, however, party affiliations generally remained weak in local legislatures, and the political agenda was set by the executive in the vast majority of localities. ${ }^{32}$ We note also that our binary definition of historical association with Islamist rebellion provides only a blunt proxy for the strength of Islamic convictions and thus the expected preferences of voters in local cultural contexts. 
Perhaps the most important potential weakness of our work is the classification of content as potentially appealing primarily to different constituencies. Though we consulted as widely as possible, we acknowledge that the process was highly subjective, and our classifications may be seen as overly cynical. Certainly, they do not reflect the true complexity, in which categories are not mutually exclusive. There is no reason, for example, that a regulation may not be enacted out of personal conviction or party ideology, and simultaneously serve the interests of power brokers while also appealing directly to the electorate. While limited existing research broadly confirms our attributions, ${ }^{33}$ more careful ethnographic research into how religious regulations are proposed, negotiated, and implemented would likely allow for a more nuanced attribution of beneficiaries and prospective benefits for different types of law. We hope that others who collect similar data prospectively will be able to develop more sensitive categorisations.

We feel it important to stress that the categorisations refer to the potential appeal of different types of regulations to different constituencies. no rigorous analysis has been undertaken to evaluate the actual relationship between the passage of shari'a laws and electoral outcomes in Indonesia. We were unable to perform this analysis using the current database because it is limited to the universe of governors and district heads who had ever passed any shari'a law. To investigate the success of their actions as an electoral strategy in Indonesia, and to compare the relative success of strategies appealing directly to voters with those conferring patronage opportunities, we would need to compare their chance of re-election with those who had never passed any shari'a law. This work is now underway, and will be reported separately.

In the interim, we encourage scholars with an interest in the relationship between the electoral process and the passage of shari'a laws to consider using the framework we propose to investigate interactions between politics and religious laws in other Muslim-majority democracies.

\section{Disclosure statement}

no potential conflict of interest was reported by the authors.

\section{Funding}

We would like to acknowledge financial support from the Faculty of 1 aw and Social Sciences at the School of Oriental and african Studies, university of 1ondon and from the Buffet Institute for Equality development and Globalization Studies at northwestern university. Their generous contributions allowed us to conduct field research for this paper.

\section{Notes on Contributors}

Elizabeth Pisani (Phd, 1ondon School of Hygiene \& Tropical Medicine) is a Visiting Fellow at KIT1V, 1eiden and a Visiting Senior research Fellow at the Policy Institute, King's College 1ondon. Her work explores the interaction between science, politics, and culture, and has focused on Indonesia. She is the author of Indonesia Etc.: Exploring the Improbable Nation. 
This is the accepted version of an article published online by Taylor and Francis in Third World Quarterly on 29 July 2016. Published version available at: $\mathrm{http}: / / w w w . t a n d f o n l i n e . c o m / d o i / f u l l / 10.1080 / 01436597.2016 .1206453$ Accepted version downloaded from SOAS Research Online: http://eprints.soas.ac.uk/22731/

Michael Buehler (Phd, The 1ondon School of Economics and Political Science) is an Senior 1ecturer in Comparative Politics at the university of 1ondon's School of Oriental and african Studies (SOaS). Specialising in Comparative Politics, his teaching and research interests evolve around state-society relations under conditions of democratisation and decentrali- sation. His book The Politics of Shari'a Law: Islamist Activists and the State in Democratizing Indonesia was published by Cambridge university Press in august 2016.

\section{Notes}

1. Elaigwu and Galadima, "The Shadow of Sharia"; Harnischfeger, Democratisation and IslamicLaw; Kendhammer, "The Sharia Controversy."

2. Haqqani and Fradkin, "Going Back to the Origins"; yavuz, Turkey; Zaman, "Pakistan."

3. Barfield, Afghanistan; Brown, Egypt; Harnischfeger, Democratisation and Islamic Law; longley, "The High Water Mark"; roy, Islam; Wiktorowicz, Islamic.

4. Brinkley Messick described Islamic law as a"total discourse'that includes religious, legal, moral, and economic rules and regulations. See Messick, The Calligraphic State, 3. Islamic law has onlybeen codified in the context of colonial transformations of Muslim countries. See Hallaq, Shari'a between Past and Present, 371-499. Therefore, a complete and mutually agreed upon canon of'Islamic law' does notexist.

5. Kitschelt and Wilkinson, "Citizen-Politician 1inkages," 8.

6. rural districts and municipalities share the third level of the administrative hierarchy in Indonesia after the national and provincial governments. They are headed by district heads and mayors, respectively. To avoid repetition, we use the term 'district'and 'district head'to cover all units and leaders at this level unless there are developments distinctive to municipalities.

7. Badan Pusat Statistik, Kewarganegaraan.

8. local regulations are adopted by the local government head together with the local parliament while executive orders are issued by the local government head alone. For brevity's sake we refer to both legal instruments as 'local regulations' only.

9. anwar, Developing Social Fiqh; Beatty, A Shadow has Fallen; nakamura, Islam and Democracy in Indonesia, 28.

10. Onishi, "Extremism Spreads across Indonesian Penal Code."

11. Buehler, "Subnational Islamization through Secular Parties."

12. Bush, "regional Sharia regulations."

13. Crouch, "Stretching the Scope."

14. Buehler,"The rise of Shari'a By-1aws."

15. Buehler and Tan, "Party-Candidate relationships."

16. Wilson, "Morality racketeering."

17. rosser et al.,"1eaders, Elites and Coalitions"; Erb and Sulistiyanto, Deepening.

18. aspinall and Sukmajati, Politik.

19. In our database, 36 regulations simply refer to prohibiting 'sins' without specifying what these are.

20. Buehler, "The rise of Shari'a By-1aws."

21. Wilson, "Morality racketeering."

22. These two provinces have adopted the highest number of shari'a regulations in Eastern Indonesia and Java respectively.

23. as mentioned above, 'districts' is the official term used for rural jurisdictions, while 'municipalities' denote urban areas. The urbanisation of Indonesia, especially on the main island Java, has turned many 'rural' districts into semi-urban landscapes in recent years.

24. For an account of why shari'a regulations have spread to East Java, see Turmudi, "Patronage, aliran and Islamic Ideologies,"38-60.

25. Tjetjep Muchtar Soleh was first elected in 2006, and re-elected in 2011. His administration had passed no shari'a regulation up until the end of our data collection in 2012.

26. anonymous, Transkrip. 
This is the accepted version of an article published online by Taylor and Francis in Third World Quarterly on 29 July 2016. Published version available at: $\mathrm{http}: / / w w w . t a n d f o n l i n e . c o m / d o i / f u l l / 10.1080 / 01436597.2016 .1206453$ Accepted version downloaded from SOAS Research Online: http://eprints.soas.ac.uk/22731/

27. Tribun Timur, Patabai, 24.

28. Patabai Pabokori, Mengewal, 133.

29. Tribun Timur, PS Daerah, 17.

30. Buehler, The Politics of Shari'a Law, 249.

31. Patabai Pabokori, personal communication, 14 September 2006.

32. Ibrahim et al., Parlemen.

33. alamsyah, Laporan.

\section{Bibliography}

alamsyah, rahman andi. Laporan Penelitian Awal: Peraturan Daerah Syariah Di Sumatera Barat (1998-2013) [Preliminary report: Shari'a regulations in West Sumatra (1998-2013)]. unpublished report, 2013.

anonymous. "Transkrip Cianjur Chep Hernawan Pendiri dan Ketua umum Gerakan Islam reformis [Transcript of Cianjur Interview with Chep Hernawan Founder and Head of Islamist reform Movement]."unpublished manuscript. 1 november, 2011.

anwar, Syafi'i M.“developing Social Fiqh : an alternative to Counter'Creeping Shariahization'?" ICIP 1, no.1, January-april, 2004.

aspinall, Edward, and Mada Sukmajati. Politik Uang Di Indonesia: Patronase Dan Klientelisme Pada Pemilu Legislatif 2014 [Money Politics in Indonesia: Patronage and Clientelism in the 2014 legislative Election]. research Centre for Politics and Government, 2015. accessed March 25, 2016. https:// digitalcollections.anu.edu.au/handle/1885/27189

Badan Pusat Statistik. Kewarganegaraan, Suku Bangsa, Agama, dan Bahasa Sehari-hari Penduduk Indonesia. [Citizenship, Ethnicity, religion and dialects of Indonesian Citizens.] Jakarta, Indonesia: Badan Pusat Statistik, 2011.

Barfield, Thomas. "afghanistan: The local and the Global in the Practice of Shari'a." In Sharia Politics: Islamic Law and Society in the Modern World, edited by robert W. Hefner, 184-185. Bloomington: Indiana university Press, 2011.

Beatty, andrew. A Shadow Falls in the Heart of Java. new york: Faber \& Faber, 2009.

Brown, nathan."Egypt: Cacophony and Consensus in the Twenty-First Century."In Sharia Politics: Islamic Law and Society in the Modern World, edited by robert W. Hefner, 94-120. Bloomington: Indiana university Press, 2011.

Buehler, Michael. "The rise of Shari'a By-1aws in Indonesian districts: an Indication for Changing Patterns of Power accumulation and Political Corruption." South East Asia Research 16, no. 2 (2008): 255-285.

Buehler, Michael."Subnational Islamization through Secular Parties: Comparing Shari'a Politics in TwoIndonesian Provinces." Comparative Politics 46, no. 1 (2013): 63-82.

Buehler, Michael. The Politics of Shari'a Law: Islamist Activists and the State in Democratizing Indonesia. Cambridge: Cambridge university Press, 2016.

Buehler, Michael, and Paige Tan. "Party-Candidate relationships in Indonesian local Politics: a Case Study of the 2005 regional Elections in Gowa, South Sulawesi Province." Indonesia no. 84 (2007): 41-69.

Bush, robin. "regional Sharia regulations in Indonesia: anomaly or Sympton?" In Expressing Islam: Religious Life and Politics in Indonesia, edited by Greg Fealy, and Sally White, 174-191. Singapore: Institute of Southeast asian Studies, 2008.

Crouch, Melissa. "Stretching the Scope of Special autonomy in aceh: The Controversial Qanun requirement for Political Candidates." Australian Journal of Asian Law 11, no. 1 (2009): 135-158.

Elaigwu, Isawa, and Habu Galadima. "The Shadow of Sharia over nigerian Federalism." Publius 33(Summer 2003), 123-144.

Erb, Maribeth, and Priyambudi Sulistiyanto. Deepening Democracy in Indonesia. Singapore: Institute of Southeast asian Studies, 2009.

Hallaq, Wael B. Shari'a between Past and Present: Theory, Practice and Modern Transformations. Cambridge: Cambridge university Press, 2009. 
This is the accepted version of an article published online by Taylor and Francis in Third World Quarterly on 29 July 2016. Published version available at: $\mathrm{http}: / / w w w . t a n d f o n l i n e . c o m / d o i / f u l l / 10.1080 / 01436597.2016 .1206453$ Accepted version downloaded from SOAS Research Online: http://eprints.soas.ac.uk/22731/

Haqqani, Husain, and Hillel Fradkin. “Going Back to the Origins.” Journal of Democracy 19, no. 3 (2008):13-18.

Harnischfeger, Johannes. Democratization and Islamic Law: The Sharia Conflict in Nigeria. Chicago, I1: Chicago university Press, 2008.

Ibrahim, anis, nuruddin Hady Sirajuddin, and umar Sholahuddin. Parlemen Lokal DPRD: Peran Dan Fungsi Dalam Dinamika Otonomi Daerah. [1ocal Parliaments: Their role and Function in Subnational Political autonomy]. Malang: Setara Press, 2008.

Kendhammer, Brandon. "The Sharia Controversy in northern nigeria and the Politics of Islamic 1aw in new and uncertain democracies." Comparative Politics 45 (april 2013): 291-311.

Kitschelt, Herbert, and Steven I. Wilkinson, eds. "Citizen-politician linkages: an Introduction.”In Patrons, Clients, and Policies: Patterns of Democratic Accountability and Political Competition, edited by Herbert Kitschelt, and Steven I. Wilkinson, 1-49. Cambridge: Cambridge university Press, 2007.

1ongley, april. "The High Water Mark of Islamist Politics? The Case of yemen." Middle East Journal 61, no. 2 (2007): 240-260.

Messick, Brinkley. The Calligraphic State. Berkeley: university of California Press, 1993.

nakamura, Mitsuo. Islam and Democracy in Indonesia: Observations on the 2004 General and Presidential Elections 6. Cambridge, Ma: Islamic 1egal Studies Program, Harvard law School, 2005.

Onishi, norimitsu."Extremism Spreads across Indonesian Penal Code."The New York Times, October 28, 2009. accessed March 25, 2016. http://www.nytimes.com/2009/10/28/world/asia/28stoning.html. Patabai, Pabokori. Mengewal Bulukumba Ke Gerbang Syariat Islam [Guiding Bulukumba towards

Gate of Syariat Islam]. Makassar: Karier utama, 2005.

rosser, a., I. Wilson, and P. Sulistiyanto."Ieaders, Elites and Coalitions: The Politics of Free Public Services in decentralised Indonesia." The Developmental Leadership Program, University of $\begin{array}{lllll}\text { Adelaide, 2011. } & \text { accessed } & \end{array}$ https://hekyll.services.adelaide.edu.au/dspace/handle/2440/71944

roy, Olivier. "Islam et Politique En asie Centrale." Archives de Sciences Sociales Des Religions 46, no. 115(2001): 49-61.

Tribun Timur."Patabai Pabokori yang mengingingkan daerahnya sebagai gudang penghapal al Quran [Patabai Pabokori wants the district to be like a Storage House for al Quran Memorizing Experts]." Tribun Timur 28 (March 2005): 24. accessed July 22, 2016. http://makassar.tribunnews.com/

Tribun Timur. PS Daerah [1ocal news]. July 28, 2006, 17. accessed July 22, 2016. http://makassar. tribunnews.com/

Turmudi, Endang. "Patronage, aliran and Islamic Ideologies during Elections in Jombang, East Java." In Elections in Indonesia: The New Order and Beyond, edited by Hans antlov, and Sven Cederroth, 38-60. 1ondon: routledge, 2004.

Wiktorowicz, Quintan. Islamic activism: A social movement theory approach. Indiana university Press, 2004.

Wilson, I. d."Morality racketeering: Vigilantism and Populist Islamic Militancy in Indonesia."In Between Dissent and Power: The Transformations of Islamic Politics in the Middle East and Asia, edited by Khoo Boo Teik, Vedi Hadiz, and yoshiro nakanishi, 248-274. 1ondon: Palgrave Macmillan, 2014.

yavuz, Hakan. "Turkey: Islam without Shari'a." In Sharia Politics: Islamic Law and Society in the Modern World, edited by robert W Hefner, 94-120. Bloomington: Indiana university Press, 2011.

Zaman, Muhammad Qasim."Pakistan: Shari'a and the State."In Sharia Politics: Islamic Law and Society in the Modern World, edited by robert W. H 
